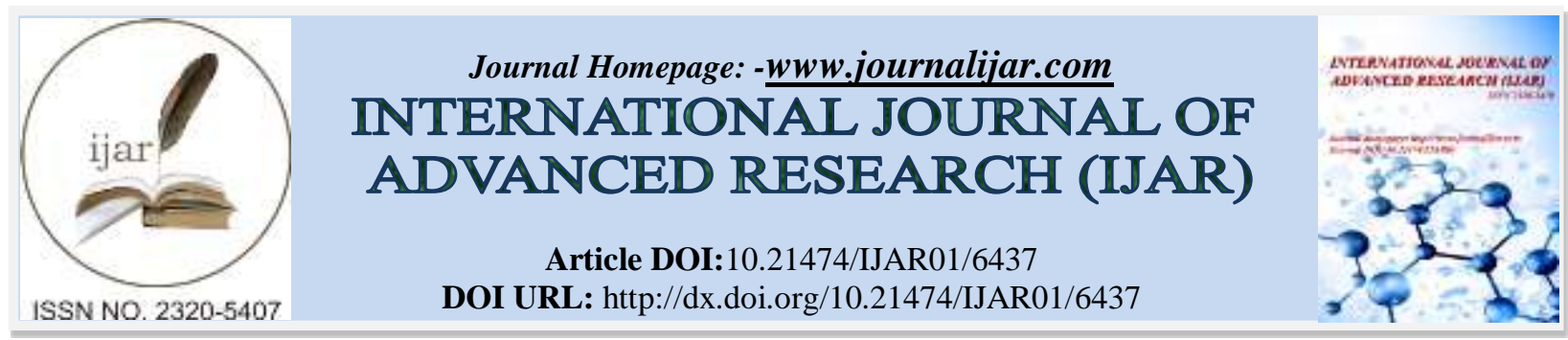

RESEARCH ARTICLE

\title{
GEOLOGY AND TYPOLOGY OF THE AU-PD-PT MINERALIZATION OF THE NORTH CORRIDOR OF THE FAR WEST BLEÏDA DEPOSIT, BOU AZZER INLIER (CENTRAL ANTI-ATLAS, MOROCCO).
}

\author{
${ }^{*}$ Wafik A ${ }^{1}$, Atif $Y^{2}$, Ait Lahna A. ${ }^{1}$ Benhammou A. ${ }^{2}$, Admou H. ${ }^{1}$, Baoutoul H. ${ }^{2}$, Bajddi A. ${ }^{2}$, Maacha L $^{2}$ And El \\ Ghorfi $\mathbf{M}^{3}$. \\ 1. DLGR Laboratory, URAC 43, Departement of Geology, Faculty of Sciences Semlalia, Cadi Ayyad University, \\ Marrakech, Maroc. \\ 2. Managem Group, Twin Center, Casablanca, Morocco. \\ 3. Department of Geology, Faculty of Sciences and Technic Gueliz, Cadi Ayyad University, Marrakech, Maroc.
}

\section{Manuscript Info}

\section{Manuscript History}

Received: 04 December 2017

Final Accepted: 06 January 2018

Published: February 2018

Keywords:-

Bleida, Far-West, Gold, Platinum, orogenic, shear-zone.

\begin{abstract}
The Far West Bleïda deposit is located in the buttonhole of Bou-Azzer El Graara at seven kilometers North West of the Bleïda mine. The geological formations of the study area are generally dipped to the north; they have more contacts at least faulted except diorites, which are intruded in basic rock. All these trainings are affected by both schistosities phases B1 and B2 of the orogeny panafricaine. The metamorphic grade increases from south to north marked by the development of metamorphic features represented in the north of the map.

The mineralization of this area is cashed in green rocks (basalt) and also in diorites intrusions. Well, the gold of the study area is associated with the S1 and S2. Four paragenetics stages of gold were pointed out: i) Gold 1, disseminated in the matrix of the rock encased; ii) Gold 2, within quartz-veins; ii) Gold 3, within iron oxide and/or carbonate; iv) and Gold 4, within later calcite late. Gold 3 is associated to Palladium or Platinum.

The mineralization is deposited in corridors shears, characterized by strong hydrothermal fluids percolate, which are associated with several types of hydrothermal alterations within mesothermal conditions.
\end{abstract}

Copy Right, IJAR, 2018,. All rights reserved.

\section{Introduction:-}

The gold deposits at Bleida Far West in the Precambrian volcanosedimentary series and are structurally controlled by N20, N60, and N120 faults in the shear corridors (Wafik et al., 2000; Wafik, 2001; El Ghorfi, 2006). The FarWest Bleida deposit is located at the SE of the Bou-Azzer El Graara buttonhole seven kilometers north-west of the Bleida mine. The district of Bleïda corresponds to a structure oriented NW-SE which extends on a length of $11 \mathrm{Km}$. A few studies have been done on the Bleida Far-West deposit. Until now, there is no genetic model and typology of this deposits based on academic study. With this contribution, we attempt to establish the typology and the genetic model. We provide a detailed geological map, petrologic features of mineralized area, detailed relationship with tectonic events related to the Bleida Far-West, and panafrican orogeny. 


\section{Materials and Methods:-}

To establish any structural, petrographic and geochemical relationship among gold, lithological hosted facies in Bleida Far West deposit, and tectonic setting, we sampled the Far West deposits sequence. Also, we mapped the area and studied the relation between ore body and tectonic structures. The samples were subject to petrographic, metallographic, microstructural, and geochemical study (in DLGR, Laboratory, Semlalia Sciences Faculty, Marrakech). The samples were analyzed by ICP-MS and Scanning Electron Microscope (SEM) in Reminex Research Center laboratory, Managem Group, Morocco.

\section{Geological Setting:-}

Located in the SE of the Bou Azzer-El Graara buttonhole, in the central Anti-Atlas, Morocco, and in the north border of West African Craton, the district of Bleïda corresponds to a structure oriented NW-SE which extends about $11 \mathrm{~km}$ in length. It was one of the most remarkable examples of copper mineralization in Morocco (Figure $1)$.

In our study area, we encountered lithological formations, either magmatic or metamorphic. Sometimes, it is traversed by veins of white sterile quartz, hematite quartz, or hematite corridors (Figure 3,4). Its formations from south to north can be quoted as follows:

In the Far West sector, two geologically different units have been identified:

1. A southern unit, called zone B, which was dominated by sedimentary rocks and intruded by a complex plutonic rocks that are traversed by basic and acid dykes.

2. A northern unit named Zone $\mathrm{C}$ to which our study area belongs. It is dominated by volcanic rocks in which two intrusions of diorite and quartz diorite are set up. It is the unit that collects the gold mineralization of the Far West.

3. The geological formations of the study area are generally dipping towards the north; they have more contact at least faulted except the diorites which are intruded in the basic rock. All these formations are affected by two schistosities of phases B1 and B2 of the panafrican orogeny. The gradient of metamorphism increases from south to north, marked by the development of the metamorphic facies north of the map.

The mineralization of this zone is encased in green rocks (basalt) and also in dioritic intrusions. Thus, the gold of the study area is associated with the schistosities S1 and S2.

Basalt of the south: it is a black effusive magmatic rock (mesocratic to melanocratic), microlitic. On the ground, it appears with a black color on patina, and they are very much silicified. It is as well marked by alteration minerals like sericite and epidote. It is structurally affected by the two types of schistosity affecting the area. The first flow schistosity is with a direction from $90^{\circ}$ to $120^{\circ}$. This time, the dip of this schistosity is southward with a value that can go up to $90^{\circ}$. The second schistosity is fractured with the same properties as the regional S2. More so, these basalts are partly cut by faults of E-W directions and they are as well crossed by slits to fill either carbonate or hematite linked to late hydrothermal circulation.

Diorite: magmatic plutonic rock with gray, whitish, and greenish or blackish elements (leucocratic). The soil sometimes appears yellowish, greyish or greenish depending on the degree of weathering. These diorites are intrusive in the basalts and do not show any contact faulted with them. Sometimes, basalt enclave in these diorites was observed in the ground. However, this leads us to conclude that the dioritic intrusion is a late event in relation to the placement of the basalts. From a structural point of view, these diorites are affected only by flow schistosity S1 (its positioning B1 post) and by shears that was marked out throughout the zone. 


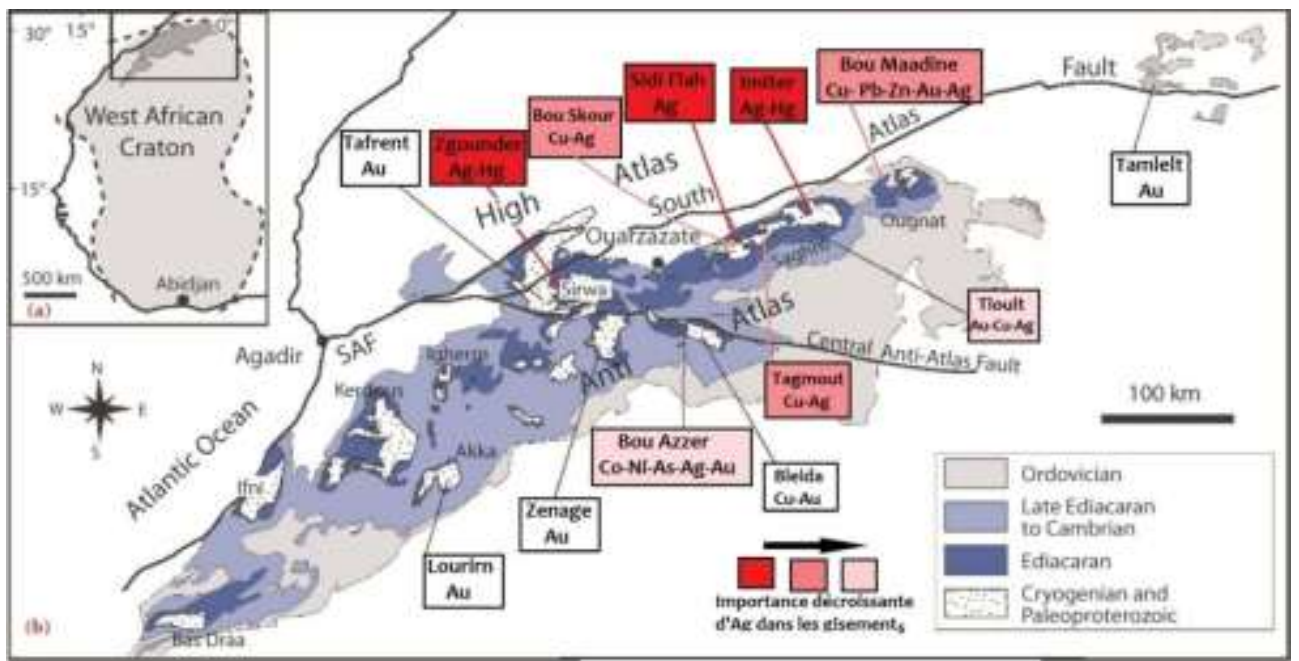

Figure 1:- Geographic localisation of Bleïda Far-West (Wafik et al., 2017)
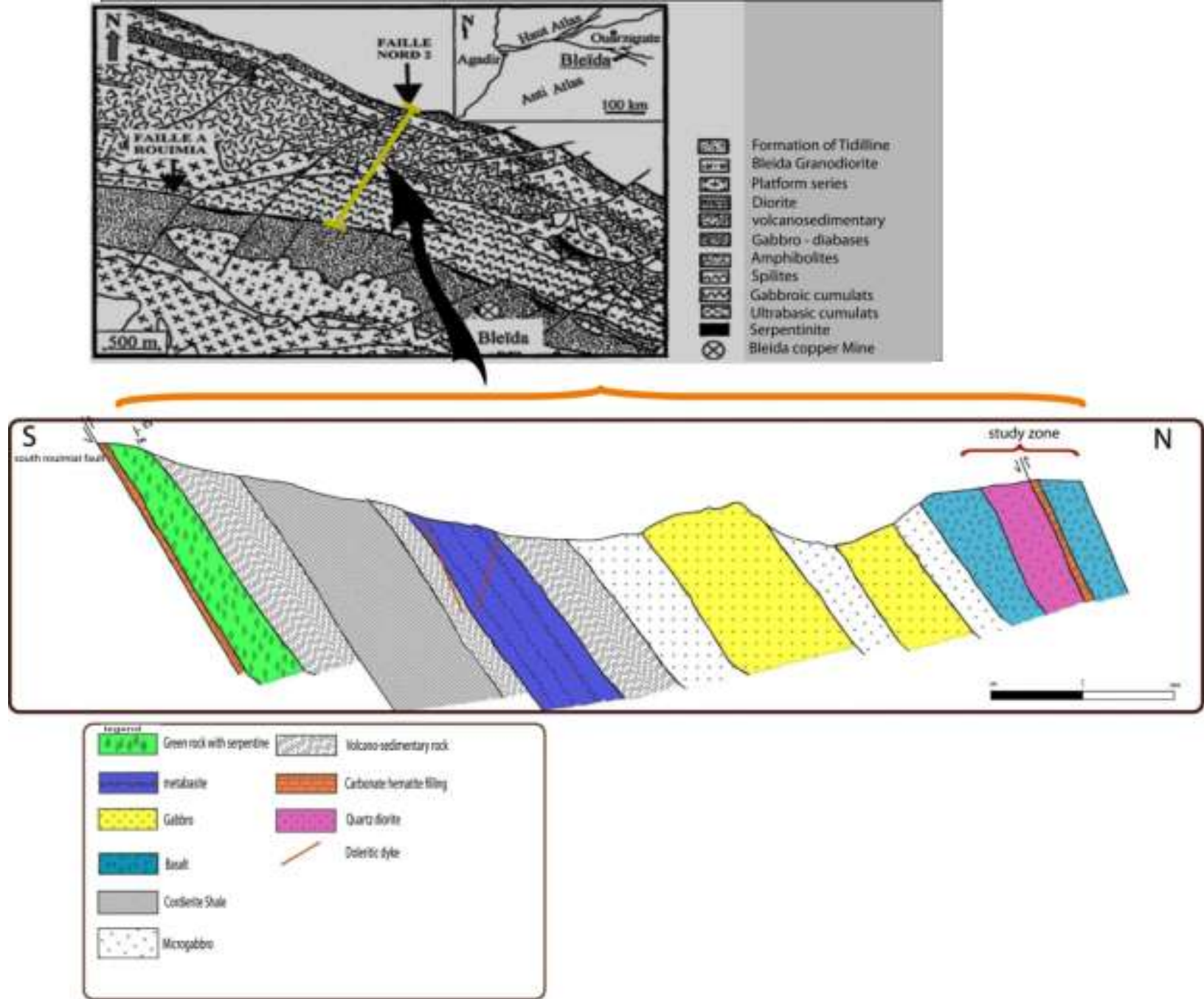

Figure 2:- Geological section crosses zone $\mathrm{C}$ with its position in the geological map of Saquaque et al. (1992)

\section{Trondhjemite:-}

This affinity of the quartz diorites has the same characteristics on the ground as the diorite except that it is richer in quartz. It is a massive terrain-oriented N100-110 direction, and it occupies $20 \%$ of our mapping area. This rock 
shows a yellow color on patina with abundance of centimeter-sized quartz grains. Like the diorite, this training shows an intrusive contact with the formations above

1. Carbonate Filling Fault (Rouimiat Nord Fault): This fault limits the southern formations (southern basalt and the dioritic intrusion) and that of the north. It is a carbonate-filled fault and in some places, we can meet it Hematite carbonate or quartz. It has a direction generally E-W more precisely of $65^{\circ}$ to $85^{\circ}$. This fault presents characters common with the fault of Rouimiat sud. The play of this fault is sinestre based on the streaks and bleachers observed in this mirror. The presence of the zones has been detected on the fault undergoing folding at the time of play.

2. Basalt of the North: It is the same as that of the south except that these basalts of north are affected by schistosities of flow S1 directed towards the north this time and not towards the south like the previous ones. It usually corresponds to a band oriented almost ENE-WSW. This is with a blackish color on patina and greenish to greyish on fresh fracture. These basalts are very silicified and hematized by the passage of quartz veinlets and/or hematite.

3. Medium Grain Tuffs: They are lithological formations of colors which can be greenish on patina. They are much affected by the two types of schistosities S1 and S2 and are generally observed in zones of weakness (talweg, fault, oued). Under the microscope, these formations show the presence of phyllo silicates through calcite flames plus quartz and chlorite. In addition, it also shows that this lithological formation corresponds to medium-grained tuffs.

4. Basic Gneissic Metastufs: They are metamorphic rock generated by the transformation of diorites. They are marked on the ground by alternating light and dark levels, i.e. madness. Under the microscope show alternations and benches with phyllo silicates with calcite banks plus recrystallized quartz. This allowed us to deduce that its formation corresponds to basic metatuffs.

5. Basic Fine Grain Tuff: This corresponds to greenish formations with an E-W direction and a dip directed towards the North. They are in turn affected by the effect of the two phases B1 and B2 of the Pan-African orogeny. Under the microscope was marked the presence of calcite flames more carbonate cross the phyllosilicates.

6. White Quartz Lodes: These are bodies of late E-W direction affected by schistosity S2 alone and not S1 and sometimes folded by Hercynian game. However, they have a brecciated texture.

7. Hematite Veins: They are E-W steered as all veins encountered were mineralized in the area in operation. Hematite is sometimes associated with quartz and sometimes carbonate. Like the white quartz veins, these veins are brecciated.

\section{Tectonics:-}

The Schistosity: There are two types of schistosity in the study area:

1 The Schistosity S1: The S1 which according to Leblanc (1975) is linked to the major pan-African phase B1. Also, it is oriented generally between $\mathrm{N} 70^{\circ}$ to $\mathrm{N} 120^{\circ}$ (Figure 5). It is a tectonic foliation, which is generally subparallel to the S0.

This schistosity affects the facies of the west in an unequal manner. It is highly expressed in levels with pelitic dominance, spotted metapelites, amphibolites, and gneisses. This is related to the rheological characteristics of these rocks. It corresponds to the major direction observed on the scale of the buttonhole. The dips of the S1 are variable $\left(5^{\circ}\right.$ to $\left.90^{\circ}\right)$. Nevertheless, this is probably due to the straightening and flattening of formations near faults and shears, and an average of $68^{\circ}$. 


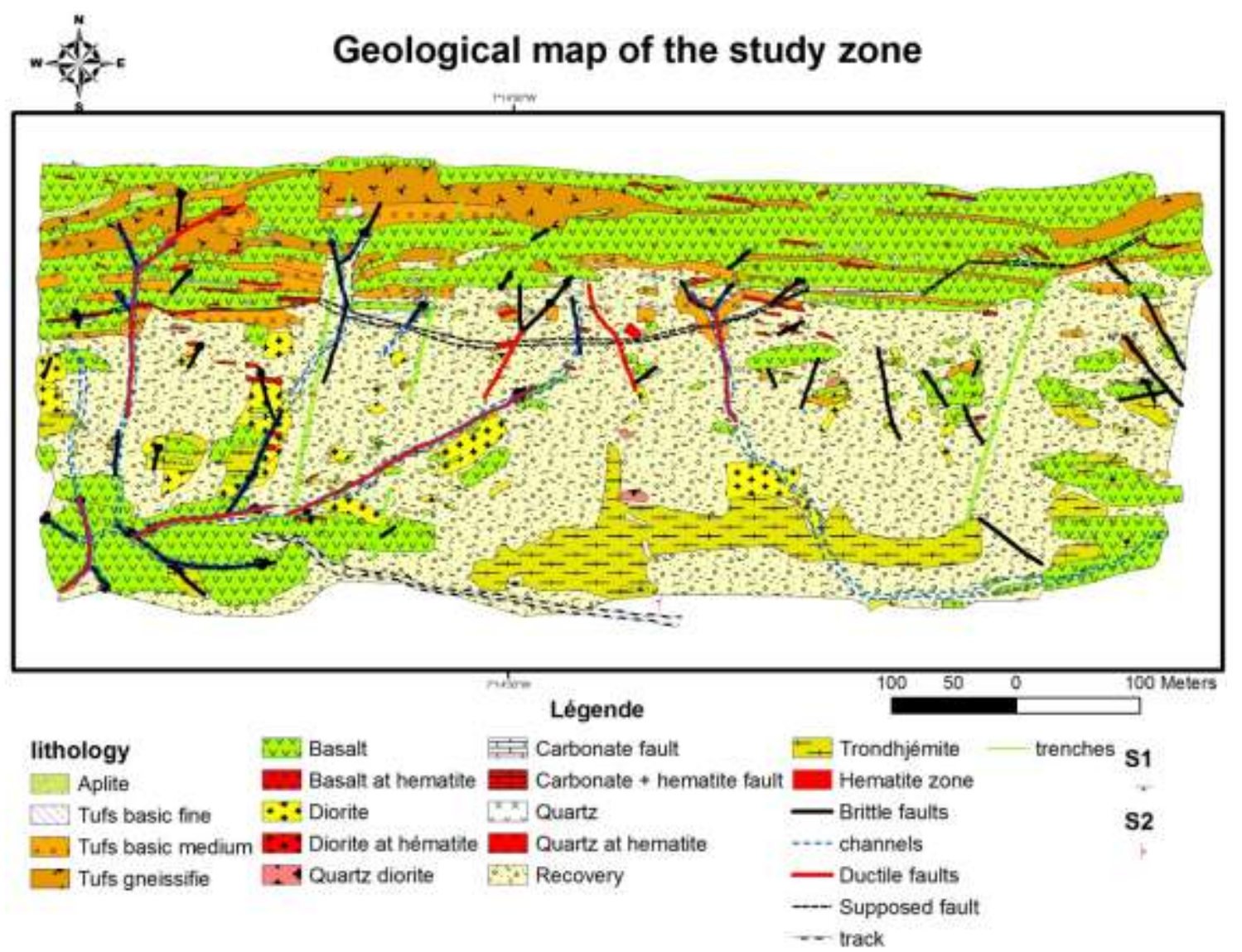

Figure 3:- Geological map of Corridor Nord Far-West $(\mathrm{CN})$ of Bleida.

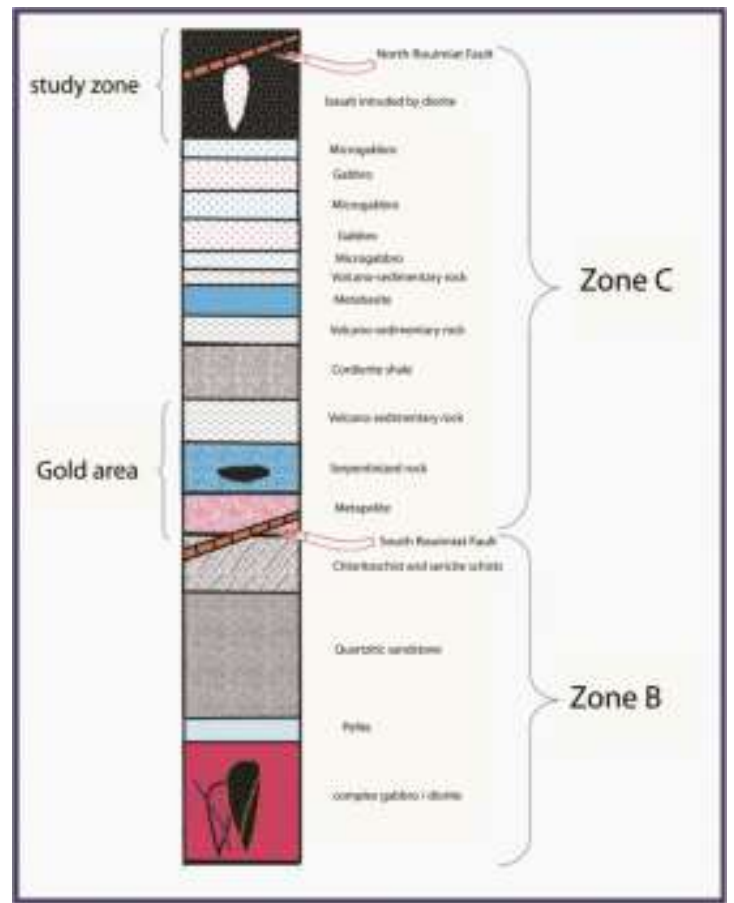

Figure 4:- The synthetic log of zones C, B, and the study area. 
Furthermore, we have shown two directions of dipping of S1. These are the first one that is big at the modo towards the south, and the second towards the north with a dominance of the plungings towards the north. This schistosity is characterized by a clear mineral orientation which results in a stretching of the minerals neoformed in the plane of S1 such as: cordierites, muscovites, chlorites, and epidotes.

The Schistosity S2 Less expressed than the previous one, this is a schistosity of dissolution. However, it affects almost all the formations of Far west except the dioritic intrusions which suggests a late implementation of these in relation to phase B1. This schistosity generally presents a NNE-SSW direction with a well-measured dip in the competent formations. It is generally between N0-N 50 (Figure 5). This schistosity may be related to the B2 phase of the panafrican orogenesis or to the Hercynian orogeny.

\section{The Folds:-}

On the study area, the folds observed are of lower frequency and are in most cases of the centimeter folds which are rarely metric. These folds are encountered generally at the level of the abnormal contacts and near the faults and shears. They are either anisopaic isoclinals or training folds which are well observed on the quartz veinlets that are very abundant in the study area and centimetric folds in the schists.

\section{The Faults:-}

The area is traversed by fault structures such as the Rouimiat Sud and Rouimiat Nord faults (N 100). These faults delimit the gold corridor of Bleida Far West and extend to the granodiorite of Bleida. There are decro-overlapping faults with a senate and carbonate filling, essentially associated with hematite and quartz.

To these faults is associated a system of faults senestre present in the same filling. In our mapped zone, it was possible to demonstrate the presence of a fault which presents the same characteristics at the level of filling and orientation with the southern Rouimiat fault that we treated. Moreover, streaks and bleeding seams observed at the level of the mirror allows us to detect a sinister game as the Rouimiat South fault movement.

\section{The Mineralized Lenses:-}

The series of quartz-hematite lenses, generally oriented $\mathrm{N} 50-80^{\circ} \mathrm{E}$, represent the major traps of gold mineralization. These lenses mark the entire mineralized series, and are probably tension joints associated with sub-East West faults. Some of them were folded during Event B2. The mineralogical study of these mineralized lenses was carried out under an optical microscope. These lenses occupy an important place in the area since they collect much of the mineralization. Generally, they have a filling of two types of quartz chronologically and logically distinct litho: the first type with dirty quartz and that is pleated and more at least interstratified in the $\mathrm{S} 1$ and sometimes folded by the phase B1, and a second quartz type plus hematite which intersects the $\mathrm{S} 1$ and is affected by the phase B1.

These slits are of variable sizes. They can be observed on a microscopic scale and sometimes reach some ten meters. This is directly related to lithology; essentially, they are highly developed in formations of silicified basalts and tuffs because of silica enrichment. However, they are forgotten based on the role of tectonics.

These lenses have been set up under a sinister shear regime. This is the reason why several lenses have been observed, and we are approaching the carbonate faults detected in our zone.

These lenses are usually surrounded by a very hematised and epididized enclosure sometimes kaolinitized with fragment of the encasement trapped in the quartz.

These lenses are affected by the different structures of brittle tectonics with, in particular, normal faults exhibiting posterior distension (post B2 phase).

\section{Microstructural Study:-}

This study is based on the observations of different oriented plates made from the samples of the mapped area. These blades are made in such a way that they can show the different structures $(\mathrm{CN}-1, \mathrm{CN}-2, \mathrm{CN}-3, \mathrm{CN}-4, \mathrm{CN}-5$, CN-7, CN-9, -14, CN-17, CN18).

The microstructures observed are generally microplates, SC structures, schistosities, and synsedimentary microfaults described by certain minerals. 


\section{Micro-Folds:-}

\section{Veins:-}

They are generally observed in a mineralized structure composed of carbonate and hematite. Microscopically, the pleated veins are to calcite well when they are affected by late microfraction (Figure 6).

\section{The SC Structures:-}

The dexter movement is described by the minerals of different facies especially quartz veins and calcite of gneissified tuffs (Figure 7).

\section{Synsedimentary Microfaults:-}

They are marked by a shift of the phyllosilicates within the tuff formations (Figure 8).

\section{The Schistosities:-}

The schistosity S1 is oriented generally at N90-N120, and is defined by the alignment of the chlorite-muscovite planes (Figure (5). This schistosity S1 is linked to the phase B1.
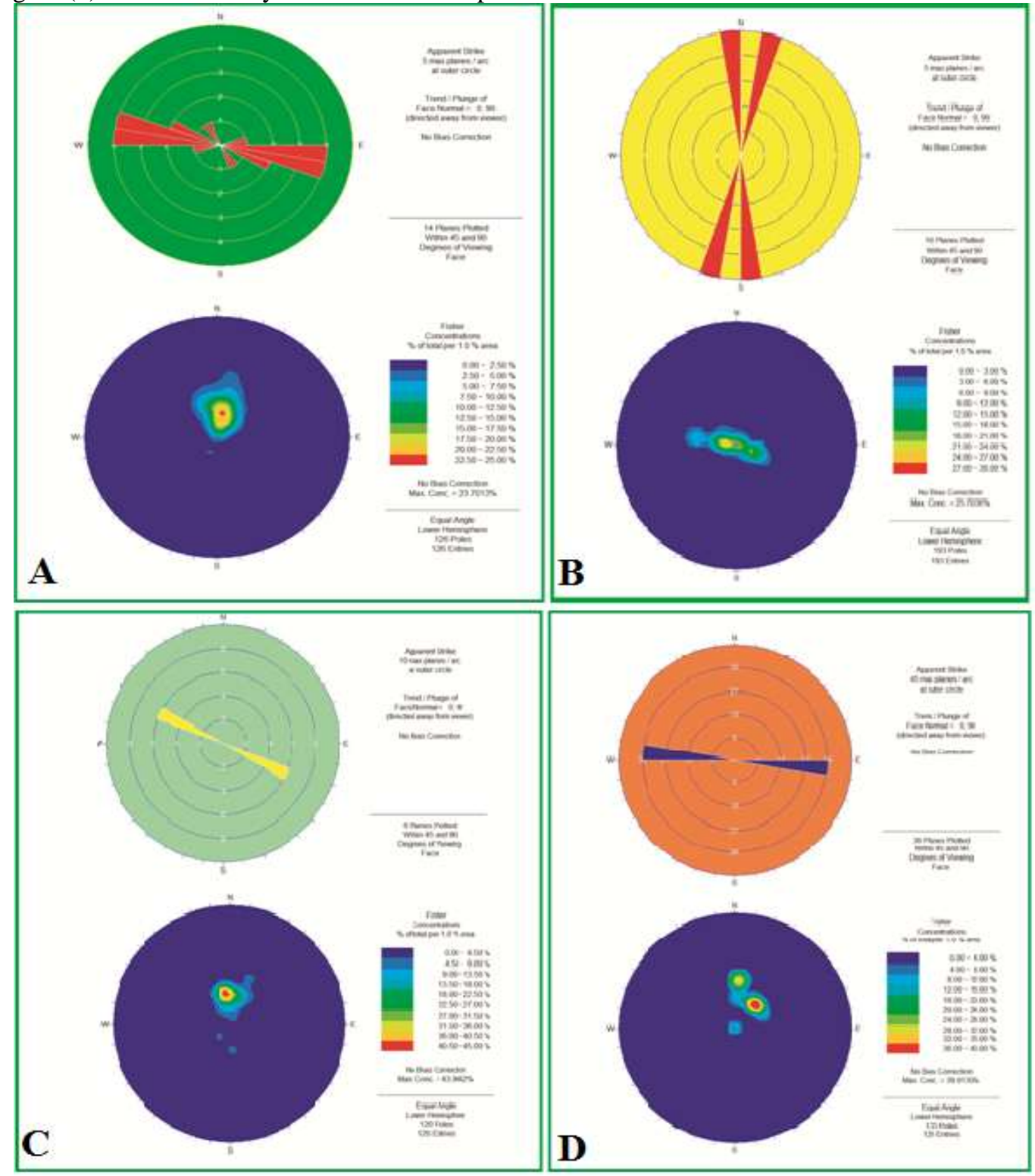

Figure 5 :- Stereographic representation of different tectonic structures encounter in the study area. A: schistosity S1; B: schistosity S2; C: different fault families of farming areas; D: veins of study area 


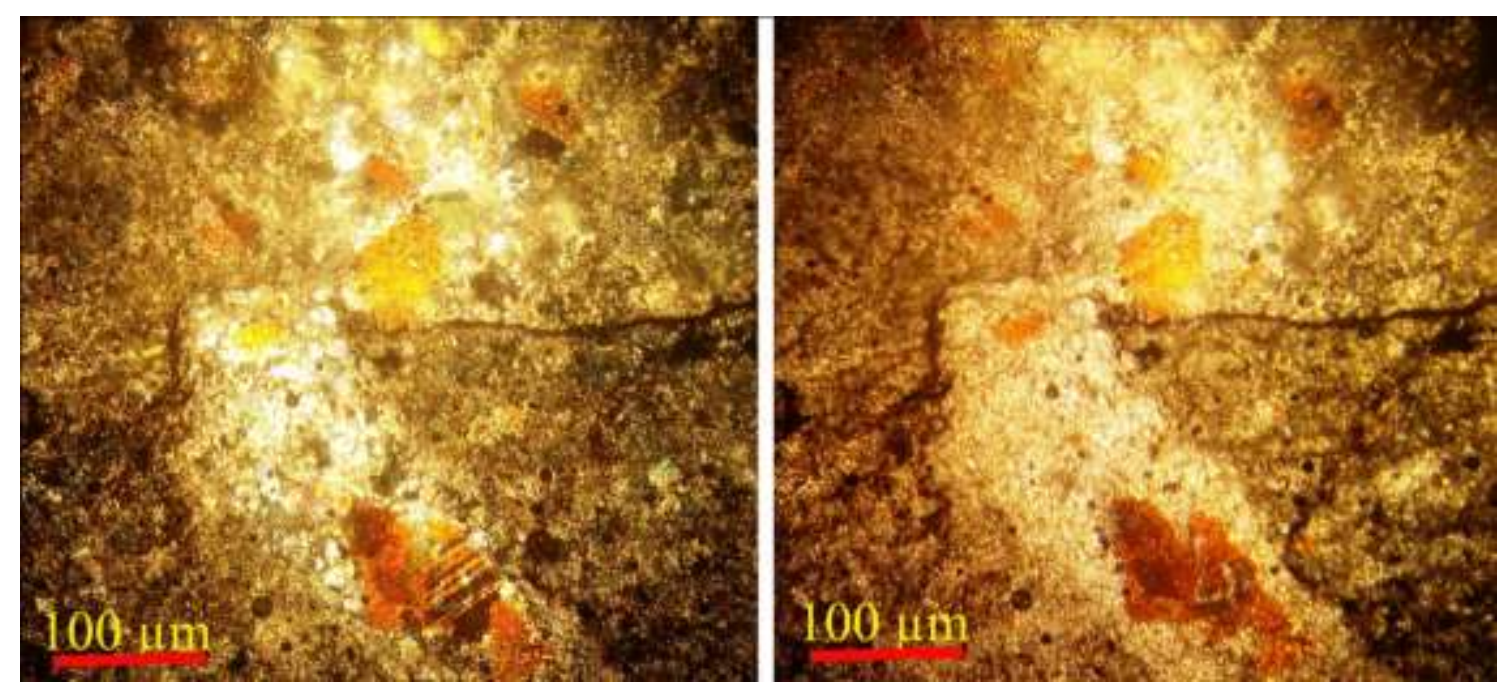

Microfold recorded in the $\mathrm{CN}-12$ thin section corresponds to a hematized quartz structure plus carbonate
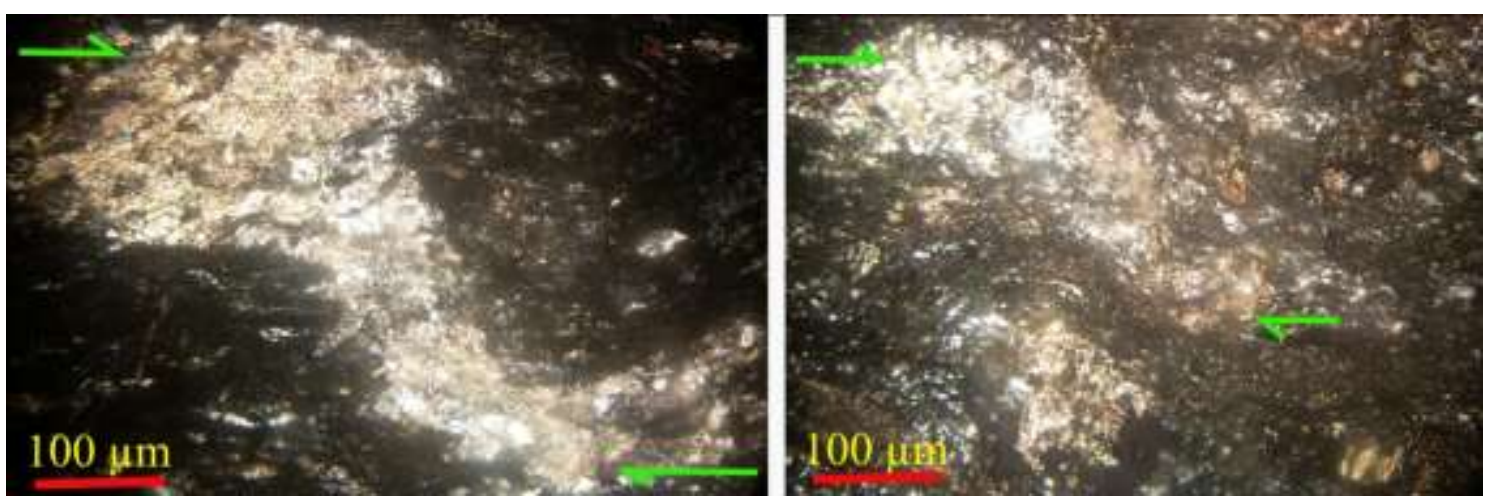

Figure 6:- Shear structures marked by the quartz veins plus carbonate blade $\mathrm{CN}-7$ corresponds to a basic tuff

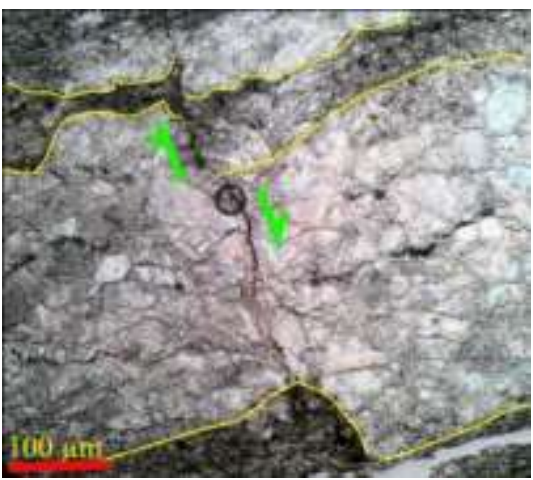

Figure 7:- Synsedimentary microfilament affects phyllosilicates in fine tuffs (CN-14 thin section) 

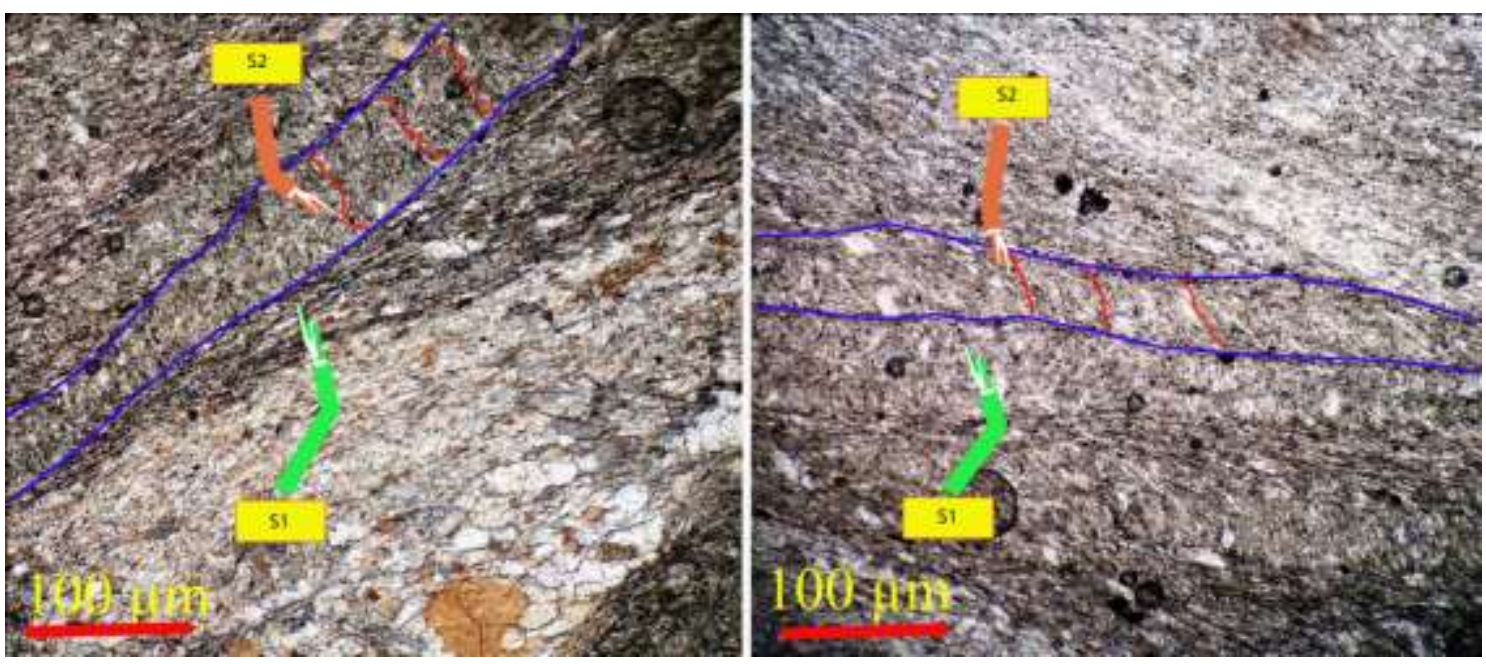

Figure 8:- $\mathrm{S} 1$ and $\mathrm{S} 2$ schistosities on a microscopic scale in medium grain basic tuffs (CN-5 thin section)

Observations of thin sections show S1 schistosity sometimes to be very rapid. This is either due to the shear zones synchronous to the $\mathrm{B} 1$ phase or to the $\mathrm{S} 2$ related to the $\mathrm{B} 2$ phase (figure 8).

The late $\mathrm{S} 2$ schistosity affects the S1 by a general direction N60.

\section{Mineralogical Study:-}

Mineralisations:-

The mineralization of Far West is native gold. This mineralization has been observed on the thin sections $(\mathrm{CN}-1$, $\mathrm{CN}-2, \mathrm{CN}-3, \mathrm{CN}-4, \mathrm{CN}-5, \mathrm{CN}-7, \mathrm{CN}-14, \mathrm{CN}-17$, and CN18) (Figure 9).

Generally, in all the studied thin sections, gold mineralization occurs in the majority of time scattered in the rock matrix, and sometimes are found in veins either of carbonate (calcite plus dolomite) or in quartz veins. The detailed study of these veins allows us to deduce the different chronologies of deposits of metallic mineralization in gold (Figure 9).

Gold in our study area was observed in basalts as well as diorites. In relation to schistosities, it has been observed that gold is sometimes associated with S1 and sometimes with S2. The gold in our zone is presented in the form of two (2) types; a very fine primary gold, whitish in color (probably rich in palladium and silver) and the secondary in reddish-colored pipettes. From the study of the relation between gold and the veins of quartz and calcite, we have concluded on the appearance of four paragenetic stages:

1. The first stage gold is disseminated in the matrix of the country rock.

2. The second stage gold appears in quartz veins.

3. The third gold stage is associated with oxides (hematites, goethite, magnetite, ilmenite).

4. The fourth stage gold is bound to veins of calcite.

According to the SEM (Scanning Electron Microscope) analysis, we have confirmed that the Or1 grains, which have a very small size and a whitish color, are Platinum grains (Figure 10). Also, the secondary gold grains appear with a coarser size (Figure 10). Thus, in the study area, we detected the presence of Bismuth that is associated most of the time with the grains of Gold. 

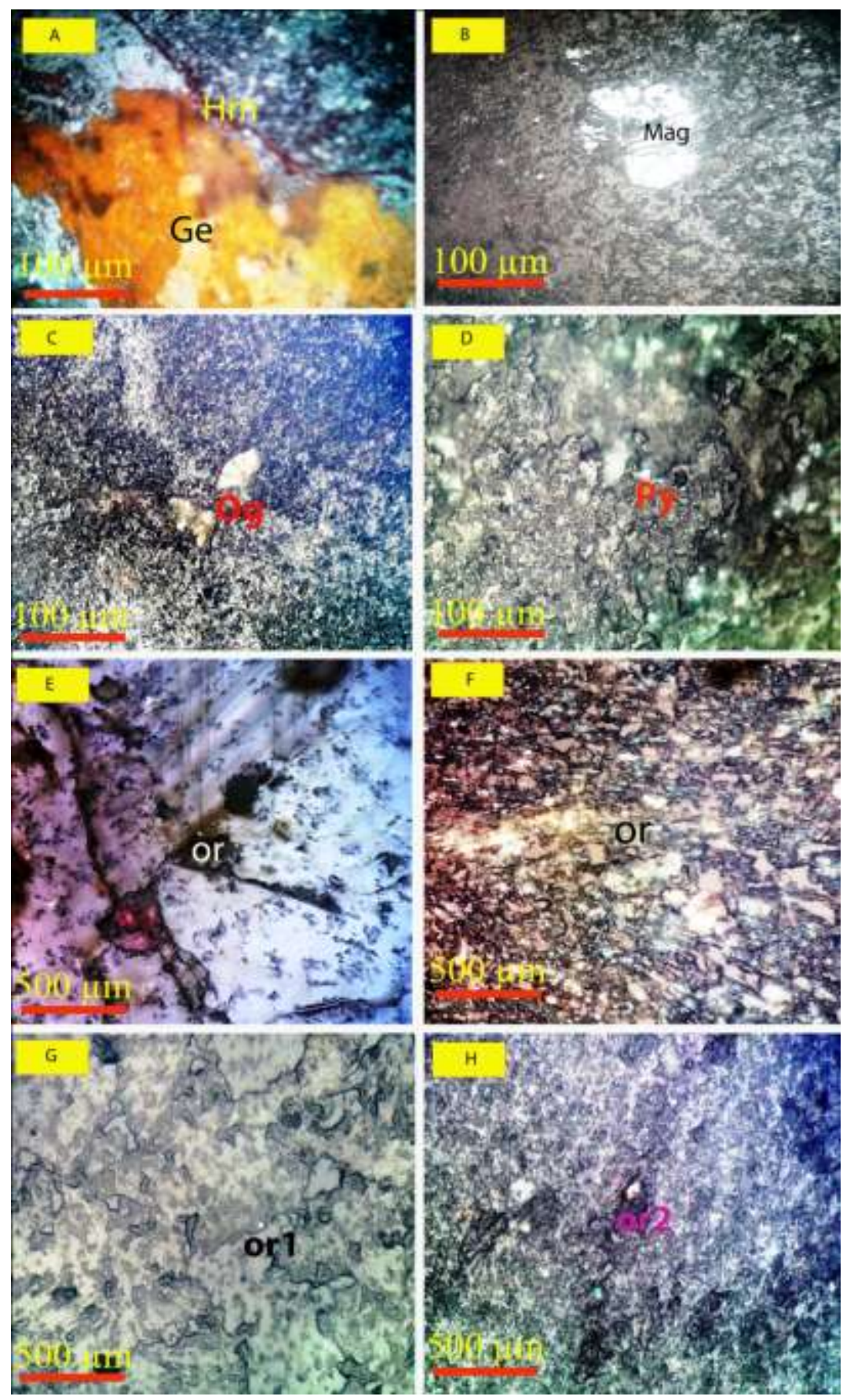

Figure 9:- Photograph of the thin sections $\mathrm{CN}-3, \mathrm{CN}-5, \mathrm{CN}-12, \mathrm{CN}-14, \mathrm{CN}-2, \mathrm{CN}-1$; A: goethite and hematite in basalt; B: magnetite in basalt; C; D: pyrite to no relation with gold in a tuff; E: gold in oxides in a slit traverses diorite; F: gold in S1 in a basic tuf; G: whitish primary gold; H: reddish secondary gold. 


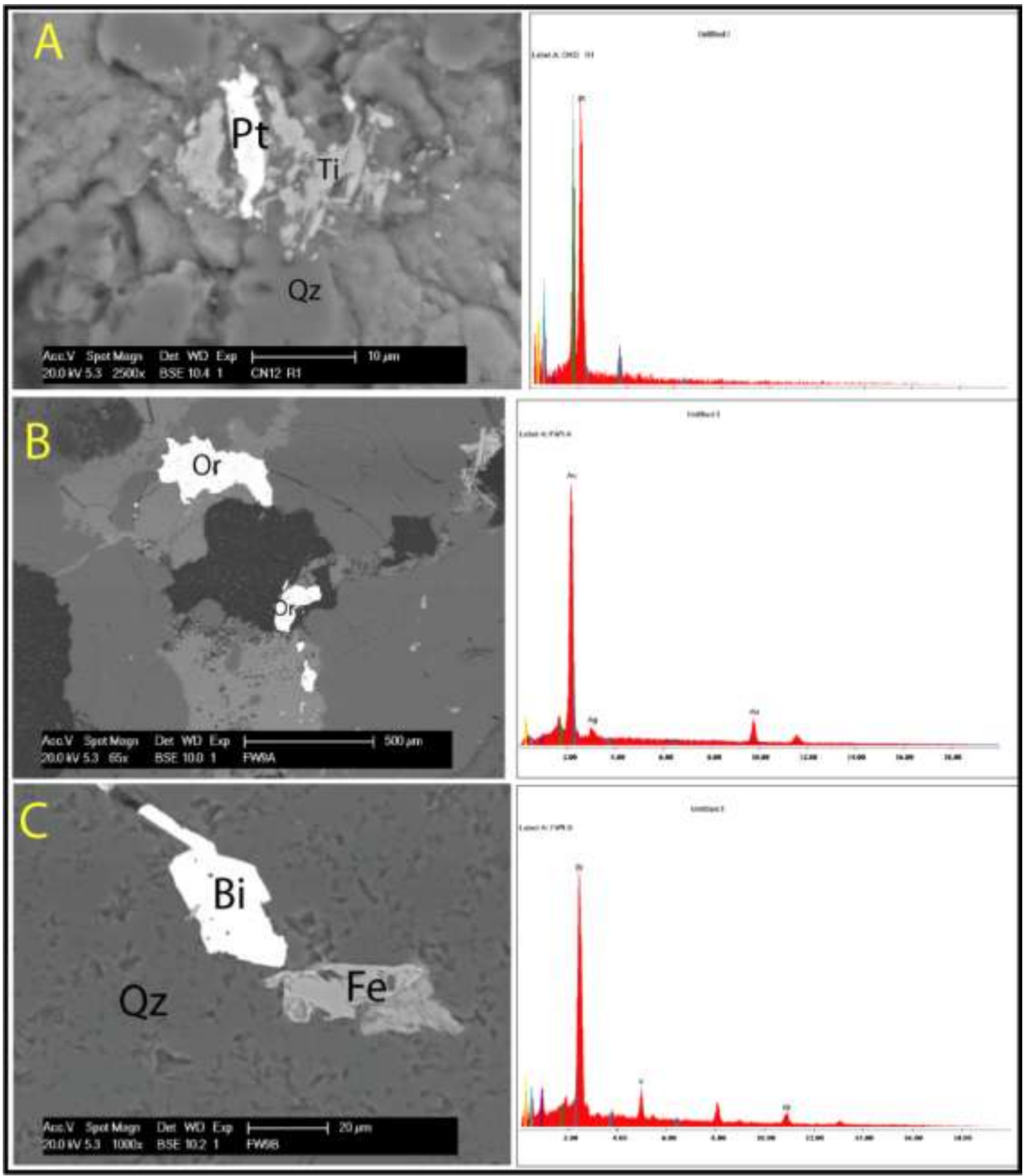

Figure 10:- SEM photo; A: Platinum grain and Rutile in a quartz; B: Secondary gold grains; C: Bismuth and Iron in a quartz vein.

\section{Paragenetic Sequence:-}

From the study of the plates, it appears that gold has been deposited in four stages; the first, and especially gold, in the matrix of the surrounding rock; the second gold is associated with quartz; and the third gold is associated with iron oxides: hematite and magnetite, goethite. This phase is associated with the ilmenite, which presents itself in a very small quantity. A late stage consists of depositing gold in calcite veins (Figure 11). 

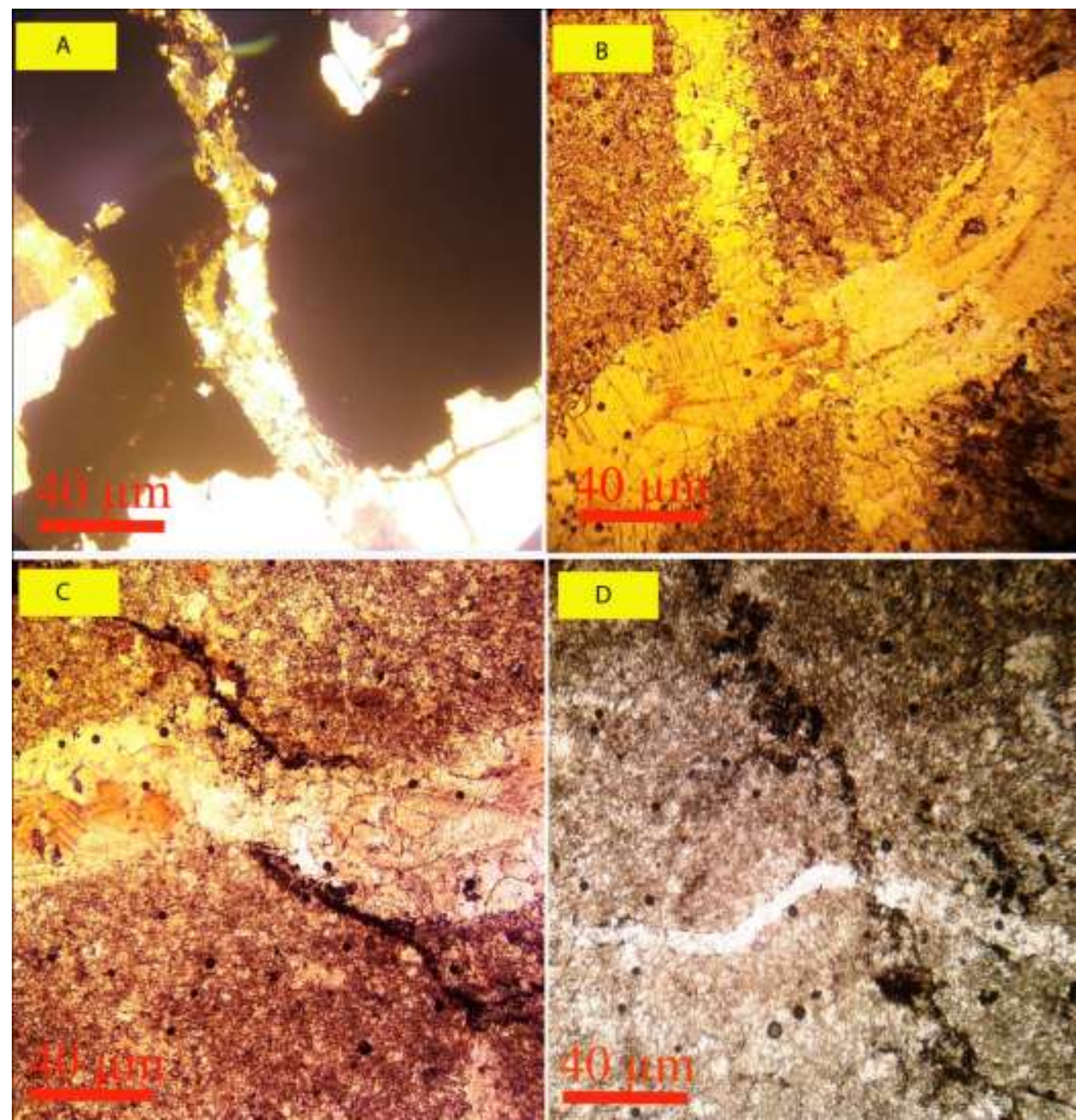

Figure 11:- Photograph of thin sections; A: a calcite vein of stage 3 cross-cut through the oxides in a hematized structure (CN-18), B: two carbonate veins crosse-cut the other in a hematite zone plus carbonate, C: iron oxides intersected by a carbonate vein of the last paragenetic stage in a hematite zone plus carbonate (CN-12), D: oxides pass through a carbonate vein).

Due to detection of different generations of the veins filling carbonate and sometimes quartz (Figure 11), we have calculated the directions of these microstructures from the thin section in order to know the major direction of the veins bearing the gold. Also, we found the result presented in the rosettes of Figure 13, whose major direction is NW-SE to EW.

Relationship between Gold and Magmatic and Tectonic Facies:-

From the study of the field, petrologic and geochemical facies, it appears that gold/Au ration shows an increase from north to south, from quartz dirorite to metabasite. However, it seems like underlying Au isotherme (Figure 13). It is also evident that gold has been deposited from oxidizing fluids within corridors as breccias and mylonite in shear zone (Figure 14). The economic gold would have been deposited in an oxydo-reduction front, materialized by an oxidizing hydrothermal fluid charged with gold and a basic rock representing a reducing. Also, it is neutral to basic $\mathrm{pH}$ field within equilibria with oxides and carbonate minerals.

\begin{tabular}{|l|l|c|c|c|}
\hline & Matrix & $\begin{array}{c}\text { Quartz veins and } \\
\text { lens }\end{array}$ & Oxides breccia & Carbonates veins \\
\hline
\end{tabular}




\begin{tabular}{|l|l|l|l|l|}
\hline Minerals & Stage 1 & Stage 2 & Stage 3 & Stage 4 \\
\hline Chlorite & & & & \\
\hline Albite & & & & \\
\hline Epidote & & & & \\
\hline Au 1 + Pl & & & & \\
\hline Quartz & & $-\ldots \ldots \ldots \ldots . .$. & & \\
\hline Au 2 + Pt & & & & \\
\hline Hematite & & & & \\
\hline Goethite & & & & \\
\hline Magnetite & & & ---- & \\
\hline Ilmenite & & & & \\
\hline Au3 + Pd & & & & \\
\hline Calcite & & & & \\
\hline Dolomite & & & & \\
\hline Au4 + Pt & & & & \\
\hline
\end{tabular}

Figure 12:- Paragenetic sequence of the study area

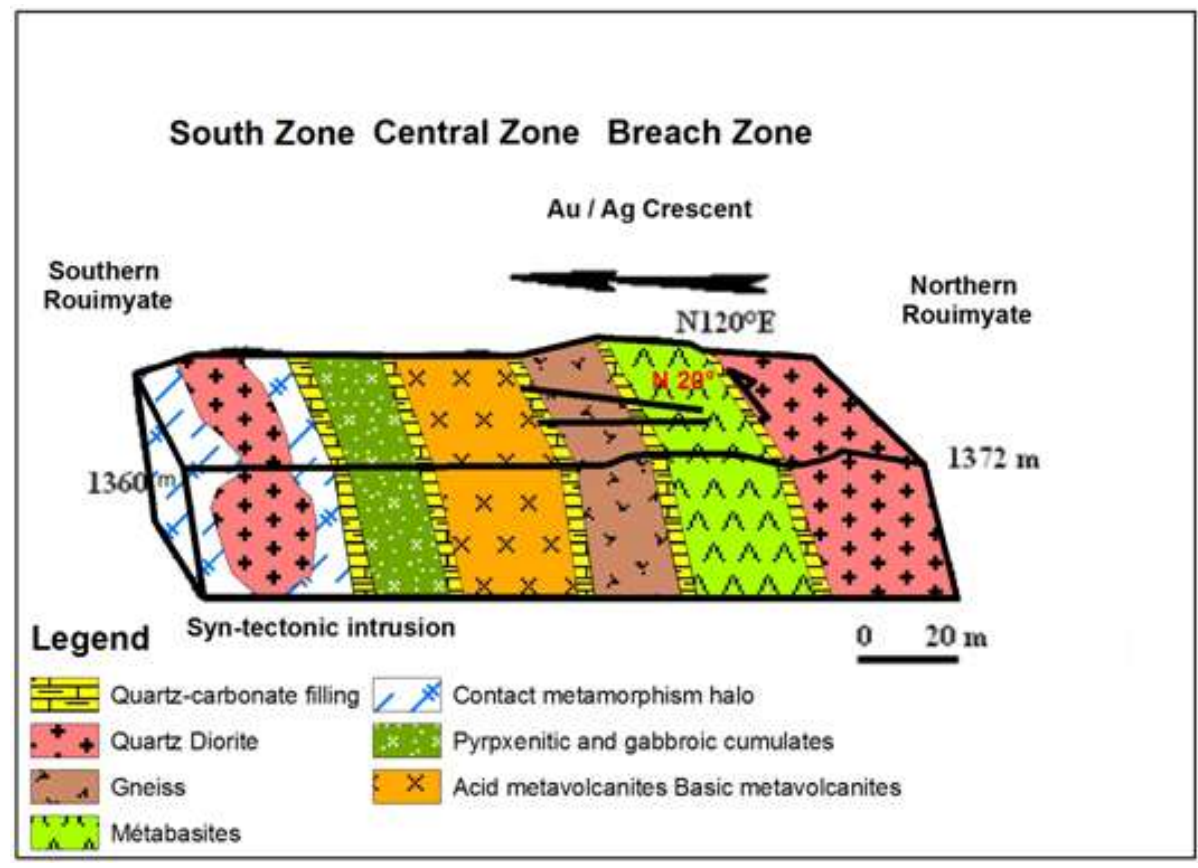

Figure 13:- Schematic block diagram showing the evolution of gold from the north to the south of the sector 


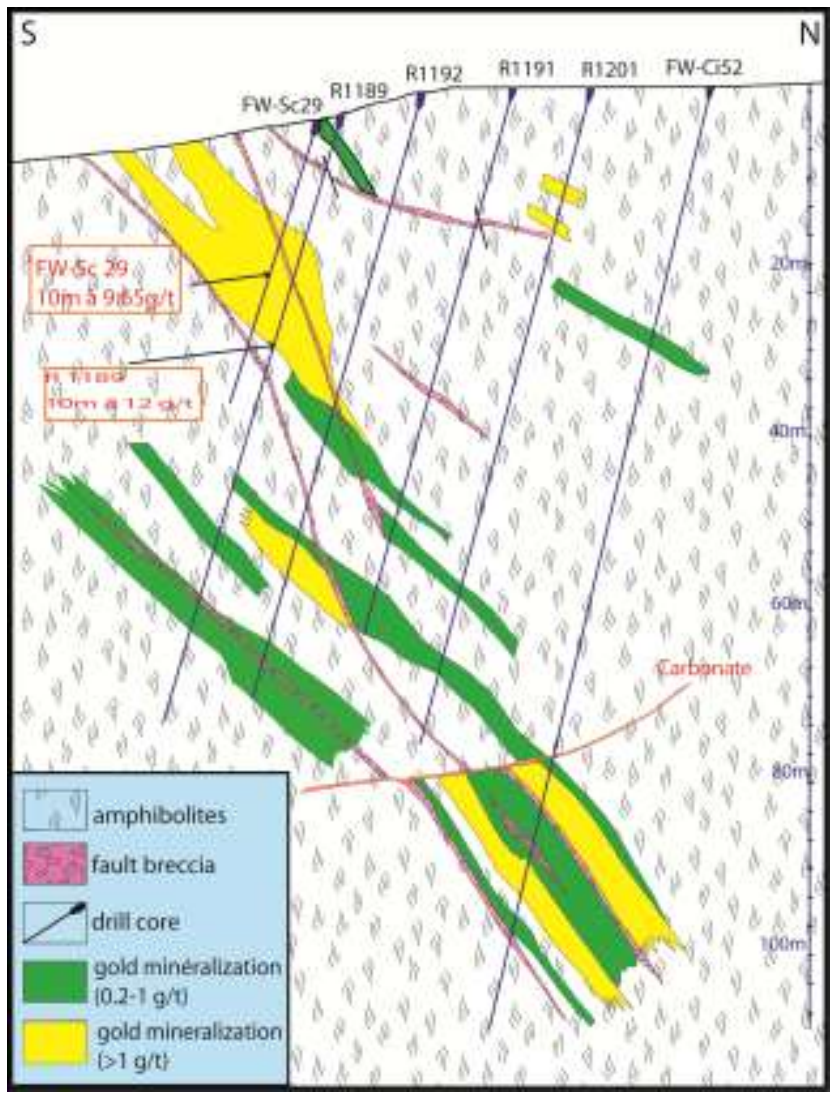

Figure 14: Cross section showing the evolution of gold contents from the north to the south within metabasite, nearby Rouimiyate North fault

\section{Type of Deposit:-}

Based on the Rose and Morrison (1988) diagrams, it can be deduced that the gold deposit of Bleida corresponds to an epithermal deposit (Figure 15). These results are consistent with data from Barakat et al. (2002) based on the study of fluid inclusions on the quartz mineralized lenses to deduce the setting temperature of the mineralization and of order $250^{\circ} \mathrm{C}$. A pressure of 2 to $4 \mathrm{MPa}$ and a depth of $2 \mathrm{~km}$ to less than $400 \mathrm{~m}$ depth is probably related to distensive tectonics.

According to the classification of Rose and Morrison (1988), the fine gold values of Far West Bleïda range from values of 0.21 to large values of 996.08. After calculating the frequency of the intervals of the fineness values, we have noticed that the most important values of the finesse in the Bleida FW are F $=200-600$. The composition of the gold grains is expressed in terms of purity by the fineness given by the following ratio, $\mathrm{F}=(1000 \mathrm{x} \mathrm{Au}) /(\% \mathrm{Au}+\%$ $\mathrm{Ag}$ ) (Rose \& Morrison, 1988). It is obtained from gold deposits based on the fineness of the Au-Ag alloy calculated from chemical analysis on samples from 120 deposits. These authors have shown that the fineness of the alloy of the plutonic deposits is: $\mathrm{F}=825$. That of the porphyry deposits: $\mathrm{F}=700-1000$ is intermediate between that of the epithermal deposits: $\mathrm{F}=440-1000$, that of the Archean deposits: $\mathrm{F}=940$, and that of the mesothermal deposits: $\mathrm{F}=$ 750-900 (Figure 16).

The Bleida Far West gold deposit ranges within the porphyry copper domain in the Diagram of Poulsen et al. (2000) (Figure 17). It has orogenic characteristics. 


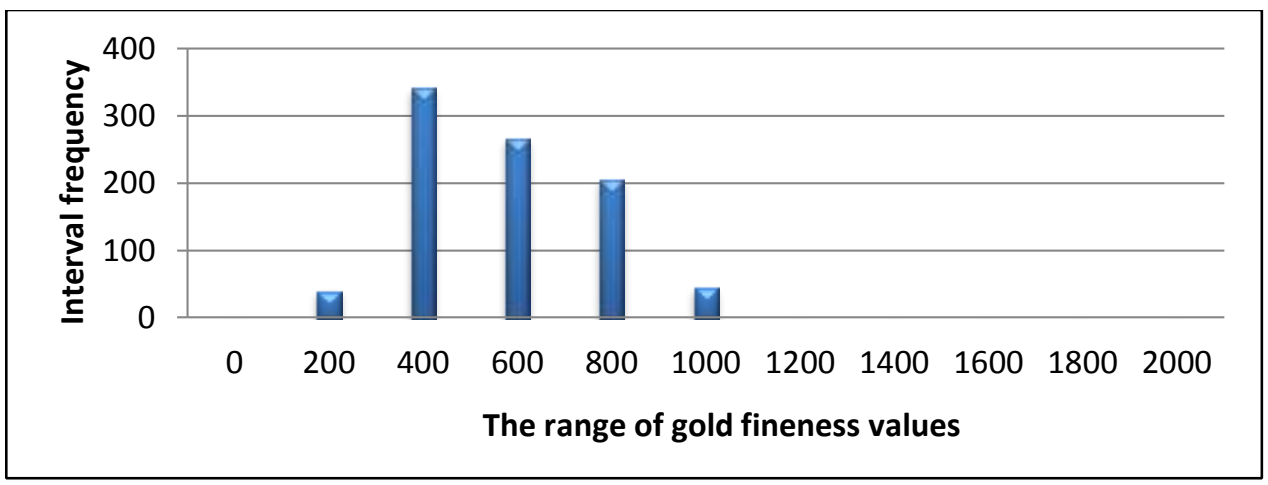

Figure 15:- Histogram of frequencies of gold fineness

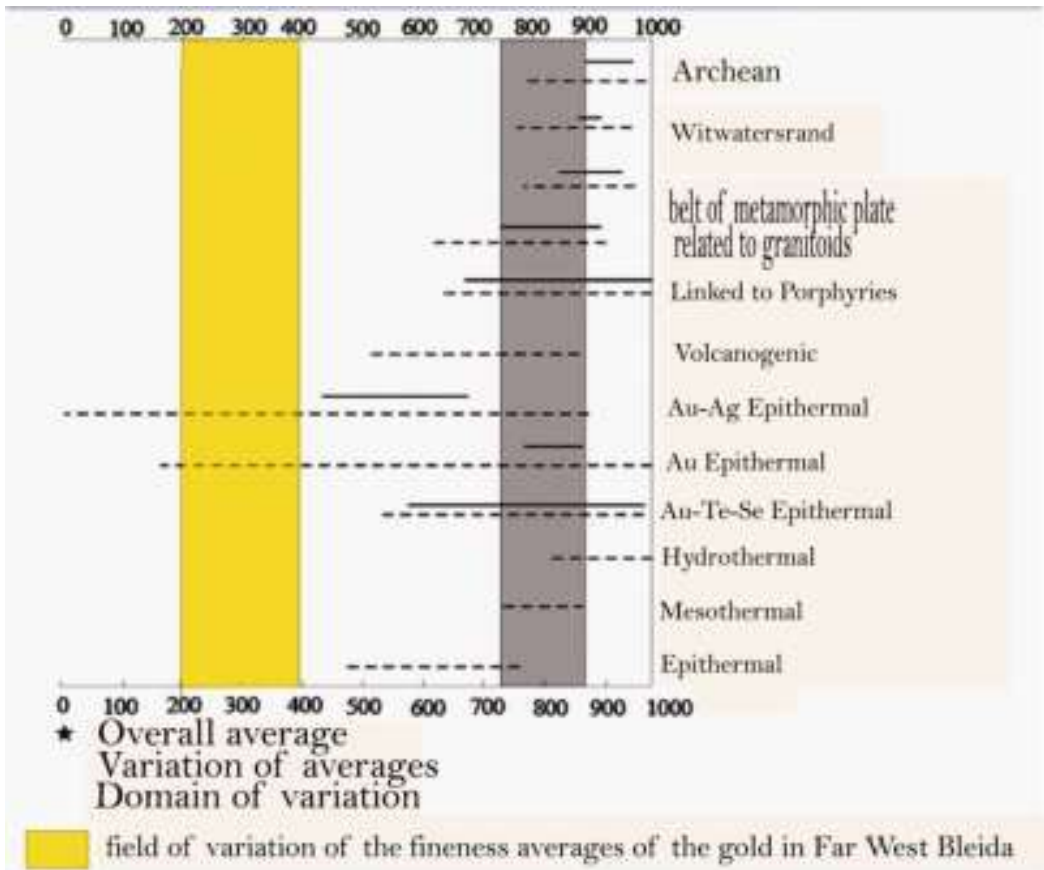

Figure 16:- Fine gold (F) of the Far West Bleida deposit in the diagram of Rose and Morrison (1988)

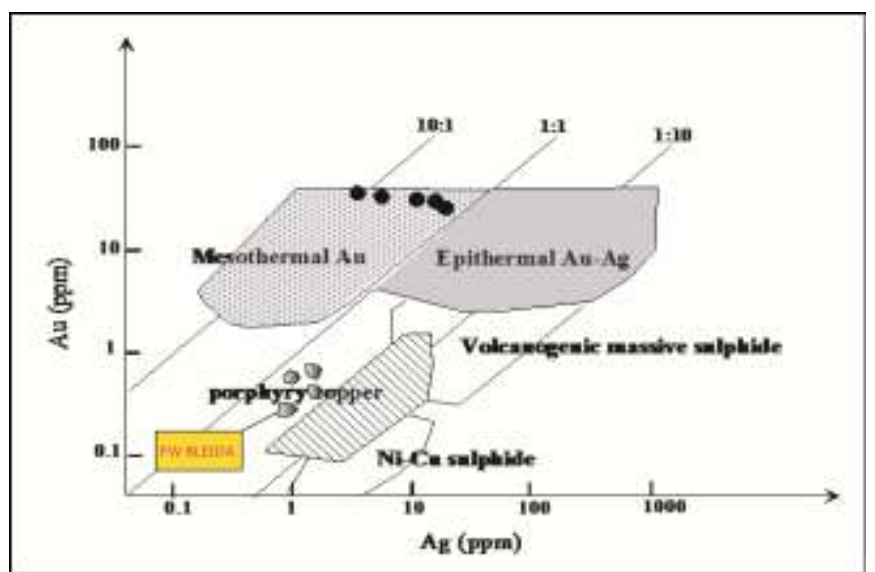

Figure 17:- Diagram of Poulsen et al. (2000) showing the situation of the Far West Bleida gold deposit in the porphyry copper domain. 
Generally, the preferred model for the formation of the gold deposit of Far West Bleida involves the input of oxidized brine from the red bedrock of the structural bottom wall into the reduced rocks of the hanging wall (Figure 18), in relation with shearing faults. This proposal is largely supported by the association of gold with hematization in green rocks. Precipitation of gold palladium would have occurred during the initial reduction of the metalliferous brine (Sillitoe, 2015).

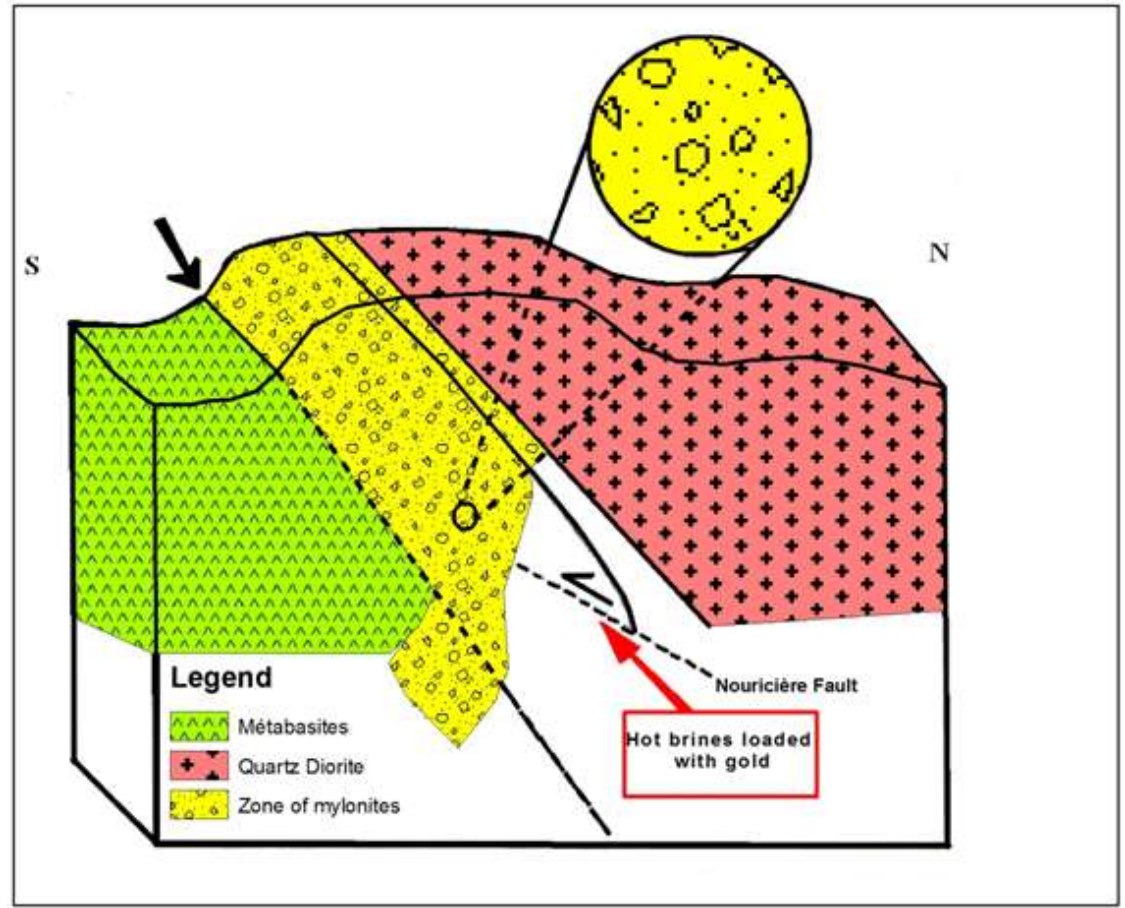

Figure 18:- Diagram of a geological section show the deposit of gold in the Far West Bleida

\section{Conclusion:-}

Metallogenic data have shown the abundance of gold with very small sizes. It is a primary gold with palladium, and then a less abundant secondary gold than the president. This has left us to conclude that our zone of study is closer to the source of gold (gold gets rid of items with displacement).

Thus, gold mineralization is noticed in diorite as well as in green rocks in the study area.

The typology of the Far West Bleïda deposit according to the cited data corresponds either to an epithermal deposit or to a porphyry type (Figure 16 and 17).

According to our studies, the main results that can be drawn are:

Geologically, mineralization is predominantly gold-engraved according to ancient studies in volcanic and volcanosedimentary rocks, which have undergone a regional metamorphism whose gradient increases from south to north as well as the intensity of deformation.

Based on the detailed mapping we carried out in the northern corridor area of the Far West, we highlighted the Rouimiat Nord fault. It is a carbonate-filled fault and/or hematite, with an E-W direction. Also, it is parallel and similar to the South Rouimiat fault.

Gold in the Far West Bleida area is often encased in greenstone. Nevertheless, for the first time in our study area, we have observed in the microscope the presence of golden grains and platinum with sizes which are very small disseminated in the matrix of intrusive diorite in the EW oriented basalt bands (this was checked by SEM analysis). Gold is divided into two types: primary gold with a whitish color rich in palladium and silver and the second reddish. Four paragenetic stages have been demonstrated in our study area: the first at Aul disseminated in the 
matrix of the surrounding rock, the second stage with quartz $+\mathrm{Au} 2$, the third stage with iron oxides and/or carbonate $+\mathrm{Au} 3$, and the fourth with late calcite $+\mathrm{Au} 4$.

Most gold grains observed in the matrix and veins have a whitish color (associated with palladium and/or silver), and a fine waist. This leads us to think that we are close to a primary gold of electrum type and palladiferous gold and therefore close to the source of gold.

Moreover, we have a small amount of sulphides which shows the deposit of gold in a medium with very low sulfur fugacity and the association with the oxides reveals a high oxygen fugacity. The association of gold with carbonates is an indicator of a neutral to basic pH. This corroborates the work of Wafik et al. (2000). The Bleida Far West deposit would be a gold deposit in the so-called "low sulphidation" category proposed by Maacha (1999) and the present study.

As for the typology, and according to the projection of the Au/Ag analyzed on the Rose and Morrison (1988) diagram, it was found that the Far West Bleida gold deposit corresponds to an epithermal type. This is the same result deduced by Barakat (2002) based on his analysis of fluid inclusions. According to Poulsen et al. (2000), the Far West Bleida deposit corresponds to a porphyry copper type. Sillitoe (2015) noted that the gold of Bleida is formed by the circulation of the oxidized brines into the red beds and is deposited in reducing rocks. In this study, gold is associated to multistage Rouimiyate shearing zone.

\section{Acknowledgement:-}

We would like to thank Managem Group for their analytical and logistic support of this project.

\section{Référencés:-}

1. Barakat A, Marignac C, Boiron MC, \& Bouabdelli M (2002). Caractérisation des paragenèses et des paléo circulations fluides dans l'indice d'or de Bleïda (Anti-Atlas, Maroc). Comptes Rendus Géosciences, 334, 35 41.

2. El Ghorfi L M (2006). Etude géochimique et métallogénique des métaux précieux (Or, Argent et Platinoïdes) associés aux minéralisations à $\mathrm{Co}, \mathrm{Ni}, \mathrm{Cr}$ de Bou Azzer-El Graara et dans la série de Bleïda Far West, AntiAtlas Maroc. Thèse Doct. ès-Sci., Univ. Cadi Ayyad, Marrakech et Centre fédéral Géosci. Ress. nat. (BGR), Hanovre, 2006. $350 \mathrm{p}$.

3. Saquaque, A., Benharef, M., Abia, H., Mrini, Z., Reuber, I. \& Karson, J (1992). Evidence for a Pan-African Volcanic Arc and wrench fault tectonics in the Jbel Sarhro, Anti-Atlas, Morocco, 1992 Geologische Rundschau 81, 1-13.

4. Wafik A., Admou H., Saquaque A., El Boukhari A., Juteau T: Les minéralisations sulfurées à Cu-Fe et les altérations associées dans les ophiolites protérozoïques de Bou Azzer et de Khzama (Anti-Atlas, Maroc), Ofioliti, 2002. p26 47-62.

5. Wafik A., Saquaque A., \& Admou H (2000). Compounds of Cu-Ni-Fein chromitites of the Proterozoic ophiolites of Bou Azzer(Anti Atlas central, Morocco). Abs. IESCA- 2000, 25-29 Sept. DEU-Izmir (Turquie),2000a. p146

6. Wafik A, Admou H, Saquaque A, El Boukhari A, \& Juteau T (2001). Les sulfures de Cu-Fe associés aux complexes filoniens des ophiolites protérozoïques de Bou Azzer et de Khzama (Anti-Atlas central, Maroc) (Abs). 18ème réunin des Sciences de la terre 17-20 Avril 2000. Paris (France).

7. Wafik A., Ramdani A., El Aouad N., El Ghazali M. 2017. A New Interpretation of Geodynamic Context and Typology of Moroccan Anti-Atlas Silver Deposits, European Scientific Journal April 2017 edition Vol.13, No.12 ISSN: 1857 - 7881 (Print) e - ISSN 1857- 7431. URL:http://dx.doi.org/10.19044/esj.2017.v13n12p424 